\title{
Comparative Study of Milk Production and Feed Efficiency Based on Farmers Best Practices and National Research Council
}

\author{
D. A. Lestari, L. Abdullah, \& Despal* \\ Department of Nutrition and Feed Technology, Faculty of Animal Science, Bogor Agricultural University \\ Jalan Agatis, Darmaga Campus, Bogor 16680, Indonesia \\ (Received 13-02-2015; Reviewed 25-03-2015; Accepted 01-06-2015)
}

\begin{abstract}
This study aimed to compare local dairy farmer ration formula with national research council in producing higher feed efficiency and milk production. This study had two stages. The first stage was in vitro study of dairy farmer rations which have different raw materials (R3, R4, and R5) with NRC based ration (R2) and Demo Farm ration (R1). The variables measured in this stage were proximate composition, volatile fatty acid, ammonia, dry matter and organic matter digestibility. The first stage used a randomized block design with five treatments, three groups of ruminal fluid, and three replications. The second stage used nine lactating cows with three periods of lactation (one, three, and other) and used a randomized block design with three treatments, three groups, and one replication. Parameters measured were dry matter intake, manure score, milk production, body weight gain, body condition score, and technical and economical efficiencies. The first stage result showed that R1, R2, and R3 were three best rations in nutrient composition and fermentability (ammonia and volatile fatty acid concentrations were optimum for microbial growth and high digestibility), so in conclusion those three rations were the best rations and should be compared by in vivo method. The result of the second stage showed that all tested rations were not significantly different in milk production, performance and efficiency, so in conclusion those three rations have the same quality.
\end{abstract}

Key words: dairy cattle, milk production, profitability, rations test

\section{ABSTRAK}

Tujuan penelitian adalah membandingkan ransum peternak dengan ransum yang disusun berdasarkan National Research Council (NRC) dalam meningkatkan efisiensi pakan, produksi susu, serta profitabilitas usaha. Penelitian terdiri atas dua tahap. Tahap pertama merupakan uji kualitas ransum peternak berbeda formula (based practise) (R3, R4, dan R5) dari ransum berdasarkan NRC (R2) dan Demo Farm (R1) secara in vitro. Variabel yang diamati adalah komposisi proksimat, volatile fatty acid (VFA), amonia, dan kecernaan bahan kering dan organik. Rancangan percobaan yang digunakan pada tahap satu ialah rancangan acak kelompok dengan lima perlakuan, tiga kelompok cairan rumen dan tiga ulangan. Penelitian tahap dua menggunakan sembilan sapi FH yang terbagi ke dalam tiga kelompok periode laktasi (dua, tiga, dan lainnya) dan menggunakan rancangan acak kelompok, yaitu tiga perlakuan, tiga kelompok laktasi, dan satu ulangan. Peubah yang diamati adalah konsumsi, produksi susu, manure score, pertambahan bobot badan, body condition score (BCS), efisiensi, dan harga ransum. Percobaan tahap satu menunjukkan bahwa R1, R2, dan R3 memiliki kandungan nutrien dan fermentabilitas yang lebih baik (VFA dan amonia optimum untuk pertumbuhan mikrob rumen, serta kecernaan bahan kering dan organik lebih tinggi) sehingga disimpulkan bahwa ketiga ransum tersebut merupakan ransum terbaik dan perlu diujibandingkan secara in vivo. Hasil penelitian tahap dua menunjukkan bahwa ketiga ransum tidak menghasilkan perbedaan yang nyata dalam produksi susu, performa, efisiensi dan harga ransum, dan disimpulkan bahwa ketiga ransum memiliki kualitas yang sama.

Kata kunci: produksi susu, profitabilitas usaha, sapi perah, uji ransum

*Corresponding author:

E-mail: despal04@yahoo.com 


\section{INTRODUCTION}

Milk is one of the important foods for fulfilling nutrition requirements. There was a wide gap between milk production and consumption. Based on data from Ditjennakkeswan (2013), Indonesia is able to meet the $20 \%$ requirement of milk consumption of 248.8 million inhabitants. The low milk production in Indonesia was due to feed problems, especially the fulfillment of animal nutrient requirements (Despal et al., 2011).

Nutrient required for milk production and maintenance is often greater than the cow's ability to consume dietary nutrient resulting in a negative nutrient balance. Harvatinet \& Allen (2005) stated that energy required for milk yield and maintenance was often greater than the cow's ability to consume dietary energy, resulting in a negative energy balance. Feeding practices in local dairy farmers do not consider animal nutrient required for maintenance and milk production. Therefore, nutrient provided for the cows could not support a long term persistency of high milk production causing a high replacement rate and low body condition score (Nugroho et al., 2015). The presence of non-fulfillment of the right nutrients was caused by using the inaccurate information of nutrient required and raw material content.

Efforts to improve local dairy productivity can be done by using the accurate information of local raw materials nutrient content and nutrient requirements, followed by appropriate formulation techniques. Information must be obtained through nutritional status information of local dairy cattle study and analysis. Observation of nutritional status information of local dairy cattle aimed to anticipate any inaccuracies ration formula due to differences in climate, soil mineral content, or animal genetic. All this time, rations formula in Indonesia or other countries have still referred to the NRC (National Research Council) (McGuffey et al., 2014), which the information contained less applicable to be used in Indonesia.

FAO (2011) stated that good practice for dairy farmers is about implementing result of previous practices on dairy farming study, as has been done by Hertanto (2014) who concluds that some local dairy farmers are able to produce milk in high quantities by using raw materials and different formulas. Local dairy farmer formula from previous study is still not confirmed its superiority in terms of cost efficiency and product quantity. Therefore, it is required to evaluate rations by considering the feed cost to get the best ration formula in terms of milk production and feed cost efficiency. Feed cost contributes (consentrate and forage) $62.5 \%$ in production of 1 L milk (Yusdjah, 2005).

Ration quality test can be done by in vitro and in vivo methods. In vitro study aimed to evaluate a ration by efficient, low cost, controlled, and making it possible to test a ration with the number of more than in vivo study. In vitro study was not able to predict consumption, productivity, and feed efficiency of livestock. Therefore, in order to predict the level of livestock productivity, the in vivo study should be done. The objective of this study was to compare based practice of traditional dairy farmer lactating cow ration formula with NRC in producing higher feed efficiency, milk production, and profitability to keep high persistency.

\section{MATERIALS AND METHODS}

The local farmer rations used in this study were the best local dairy farmer rations from nutritional status information of local dairy cattle. The first stage was in vitro study of three traditional dairy farmer rations (R3, R4, and R5) with NRC based ration (R2) and Demo Farm ration (R1), with three replications and three ruminal liquids of cows. Meanwhile, the rations used in the second stage were the three best rations in obtained from in vitro study. The second stage used nine lactation FH cows which were grouped into three lactation periods (two, three and other) and three to five month in milk (lactation). Test ration formulas of the first stage were shown in Table 1. Test ration formula of the second stage was shown in Table 2. Mako concentrate was used in this study is produced by Koperasi Peternak Sapi Bandung Utara (KPSBU) and many dairy farmers in Lembang used it as their cattle main feed.

\section{Preparation of Test Feeds and Objects of Treatment}

The first stage materials were prepared, dried, milled, and mixed according to the formulas in Table 1. In the first study (in vitro method) each test rations were made in laboratory scale as many as 100 g per ration, but test rations in the second study were made according to body weight of the cows.

\section{Chemical Composition, Non Structural Carbohydrate, and in Vivo Method}

The chemical compositions (dry matter, crude protein, ether extract, and crude fiber) of test feeds were analyzed according to the procedure of AOAC (2005). The structure of the cell wall (cellulose, hemicellulose, lignin, and sillica) used method as practiced by Kaldmae et al. (2009). The experiment was carried out for seven weeks with two weeks preliminary period and five weeks for treatment. Feed intake and milk production were measured every day. Feed intake was recorded daily by weighing feeds offered to and refused by the

Table 1. Percentage of ration composition in in vitro test (\%)

\begin{tabular}{lrrrrr}
\hline Ration composition & \multicolumn{1}{c}{ R1 } & \multicolumn{1}{c}{ R2 } & \multicolumn{1}{c}{ R3 } & \multicolumn{1}{c}{ R4 } & \multicolumn{1}{c}{ R5 } \\
\hline Concentrate & 50.091 & 17.408 & 35.144 & 11.881 & 34.723 \\
Casava meal waste & 0.000 & 24.455 & 17.572 & 47.525 & 24.802 \\
Soybean curd waste & 0.000 & 9.180 & 5.246 & 7.093 & 1.481 \\
Waste of soy sauce & 0.000 & 1.932 & 0.000 & 0.000 & 0.000 \\
Coconut meal & 0.000 & 6.133 & 0.000 & 0.000 & 0.000 \\
Soybean meal & 0.000 & 7.747 & 0.000 & 0.000 & 0.000 \\
Mineral mix & 0.125 & 0.415 & 0.039 & 0.000 & 0.000 \\
Elephant grass & 44.297 & 32.729 & 41.999 & 21.298 & 23.712 \\
Corn silage & 5.486 & 0.000 & 0.000 & 0.000 & 0.000 \\
Field grass & 0.000 & 0.000 & 0.000 & 12.202 & 15.283 \\
& 100 & 100 & 100 & 100 & 100 \\
\hline
\end{tabular}

Note: $\mathrm{R} 1=$ Demo farm ration; $\mathrm{R} 2=\mathrm{NRC}$ based ration; $\mathrm{R} 3, \mathrm{R} 4$, and $\mathrm{R} 5=$ dairy farmer rations. 
cow. Milking of cows were performed twice daily at 4.00 am and $3.00 \mathrm{pm}$. Body weight gain was calculated by calculating the difference between the pre treatment body weight with the last treatment body weight.

\section{Quality Test Feeds by in Vitro Method}

In vitro method used the method as practiced by Sretenovic et al. (2008) to measure dry matter and organic matter digestibility. $\mathrm{NH}_{3}$ and VFA concentration in the rumen were measured according to procedure as practiced by Pen et al. (2006).

\section{Body Condition Score and Manure Score Evaluation}

Body condition score (BCS) was evaluated by observation and palpation of the backbone, loin, and rump to see fat deposits. BCS values ranged 1.0-5.0 started from very thin to obese (Berry et al., 2007a). Evaluation of feces was measured according to procedure as practiced by Wells (2013) and manure score values ranged 1.0-5.0 started from very liquid to high consistency. Manure score is used to see a digestion problem, by observing feces stack height, feces color, feces consistence, screening, and washing of feces.

\section{Technical and Economical Efficiency}

Technical efficiency (Linn, 2006) $=$ milk production $/$ dry matter intake

Economical efficiency $($ Casper, 2008) $=($ milk price $x$ milk production)/feed cost

Feed cost/liter milk (Linn, 2006) $=$ feed cost $/ \mathrm{milk}$ production

\section{Experimental Design}

The first study used a randomized block design with five treatments, three groups, and three replications, meanwhile the second study used a randomized block design with three treatments, three groups, and one replication with treatment as follows:
$\mathrm{R} 1=$ Demo Farm ration

$\mathrm{R} 1$ = NRC based ration

$\mathrm{R} 3, \mathrm{R} 4$, and R5 = Local dairy cattle farmer rations

Grouping in the first study was based on ruminal fluid of cows, and grouping in the second study was based on lactation period (two, three, and other).

\section{Data Analysis}

Statistical analysis used in in vitro study was randomized block design with five rations, three groups and three replications, while in vivo study was randomized block design with three rations, three groups, and one replication. Data were analyzed by analysis of variance, except for milk production, the data were analyzed by using the analysis of covariance and Duncan's multiple range was used to separate treatment means, when probability was $<0.05$ (5\%) (Kusriningrum, 2011).

\section{RESULTS AND DISCUSSION}

\section{Proximate Composition and Non Structural Carbohydrate}

Most of dairy farmers in Lembang used mako concentrate as the main feed, but their feeding were being added other feeds such as soybean curd waste, cassava waste, and soybean meal. Mako concentrate used in this study is produced by KPSBU. Most of dairy farmers in Lembang were joined as members of cooperation so they were used mako concentrate as their cattle main feed. Ration formulas used by farmers were different and they have impacts on ration quality.

Feed quality based on proximate composition and non-structural carbohydrate is shown in Table 2. Based on the analysis of variance, the crude protein of the five rations tested were significantly different $(\mathrm{P}<0.05)$. These differences can be caused by differences in the type of feed material used and the amount or percentage of its used. R2 was a test ration with the highest average levels of crude protein $(21.77 \%)$, composed of several protein sources that were waste of soy sauce, soybean curd waste, coconut meal, and soybean meal. Crude protein in R2 was high enough $(20.72 \%)$ than R3, R4,

Table 2. Ration quality based on proximate composition and non structural carbohydrate (100\% DM)

\begin{tabular}{lccccc}
\hline \multicolumn{1}{c}{ Variables } & R1 & R2 & R3 & R4 & R5 \\
\hline Dry matter & 56.68 & 57.47 & 57.07 & 58.89 & 61.61 \\
Ash & $13.27 \pm 0.18^{\mathrm{b}}$ & $16.04 \pm 2.26^{\mathrm{ab}}$ & $14.73 \pm 0.43^{\mathrm{b}}$ & $18.61 \pm 3.19^{\mathrm{a}}$ & $13.76 \pm 1.88^{\mathrm{b}}$ \\
Beta-N & $42.00 \pm 1.14^{\mathrm{b}}$ & $40.87 \pm 2.03^{\mathrm{b}}$ & $40.39 \pm 2.03^{\mathrm{b}}$ & $48.16 \pm 3.21^{\mathrm{a}}$ & $47.47 \pm 3.91^{\mathrm{a}}$ \\
Crude protein & $20.72 \pm 0.14^{\mathrm{ab}}$ & $21.77 \pm 1.65^{\mathrm{a}}$ & $18.87 \pm 1.09^{\mathrm{bc}}$ & $11.48 \pm 0.29^{\mathrm{d}}$ & $17.29 \pm 1.11^{\mathrm{c}}$ \\
Ether extract & $2.62 \pm 0.15^{\mathrm{a}}$ & $1.47 \pm 0.04^{\mathrm{b}}$ & $2.29 \pm 0.31^{\mathrm{a}}$ & $1.30 \pm 0.22^{\mathrm{b}}$ & $1.47 \pm 0.17^{\mathrm{b}}$ \\
Crude fiber & $21.39 \pm 1.48^{\mathrm{a}}$ & $19.85 \pm 0.45^{\mathrm{a}}$ & $23.71 \pm 1.33^{\mathrm{b}}$ & $20.44 \pm 0.79^{\mathrm{a}}$ & $20.01 \pm 1.74^{\mathrm{a}}$ \\
Hemicellulose & $22.25 \pm 1.50^{\mathrm{ab}}$ & $19.29 \pm 2.58^{\mathrm{b}}$ & $26.43 \pm 1.63^{\mathrm{a}}$ & $26.00 \pm 4.49^{\mathrm{a}}$ & $27.26 \pm 3.20^{\mathrm{a}}$ \\
Cellulose & $24.61 \pm 4.08$ & $20.73 \pm 1.63$ & $22.58 \pm 0.66$ & $22.17 \pm 2.50$ & $23.21 \pm 1.44$ \\
Lignin & $8.19 \pm 1.32$ & $6.82 \pm 0.86$ & $6.23 \pm 0.16$ & $6.14 \pm 0.51$ & $8.21 \pm 2.68$ \\
Silica & $2.93 \pm 0.28$ & $5.56 \pm 1.80$ & $5.11 \pm 1.31$ & $5.87 \pm 3.80$ & $4.64 \pm 0.41$ \\
\hline
\end{tabular}

Note: Means in the same row with different superscripts differ significantly $(\mathrm{P}<0.05)$. R1= Demo Farm ration; $\mathrm{R} 1=\mathrm{NRC}$ based ration; R3, R4, and R5= local dairy cattle farmer rations. 
and R5. The high protein content is caused by the higher use of corn silage and mako concentrate. Despal (2007) reported that the improvement of crude protein quality was also shown by the silage treatment. R3, R4, and R5 were the local dairy farmer rations that were mostly composed of the same materials (mako concentrate, cassava waste, soybean curd waste, and elephant grass) but the percentages of feed materials used were different. Crude protein of R3 was higher than R4 and R5, because mako concentrate and forage in R3 were higher. R4 and R5 were composed of the higher cassava waste. Cassava waste has low protein content. Despal et al. (2011) reported that crude protein in cassava waste was only $2.02 \%$. Crude protein of R4 was lower than the other test rations, because the percentage of cassava waste was higher while the percentage of mako concentrate was very low.

Based on the analysis of variance, the crude fat of the five rations tested were significantly different $(\mathrm{P}<0.05)$. Crude fat in R1, R2, and R3 were higher than other rations, because the percentage of concentrates and forages used in the three rations tested were higher. The similar result with crude fiber, the five rations tested provided a significantly different effects on crude fiber and hemicellulose $(\mathrm{P}<0.05)$. R1 and R3 had higher crude fiber contents than the other three rations, but they could still be digested in rumen. Nuhuyanan (2010) stated that the crude fiber of feed with less than $44.57 \%$ was feasible and could be consumed and digested well by cows (50.3\%-61.56\%). However, the fiber structure (lignin, cellulose, and sillica) of the five rations tested were not significantly different.

\section{Quality of Diets Based on in Vitro Method}

Evaluation of feed quality by in vitro was conducted to know the quality of diets in fermentative and utility in the rumen. In the rumen, diet will be fermented to produce VFA and ammonia as the main product of fermentation in the rumen. Dry matter digestibility and organic matter digestibility are characteristics of diet utility in the rumen (Despal et al., 2011). The concentration of VFA, ammonia, \% DMD, and \% OMD were presented in Table 3.

Volatile fatty acids are byproducts of rumen microbial fermentation and represent the main supply of metabolizable energy for ruminants (Busquet et al., 2006). Based on the analysis of variance, VFA concentrations of the five rations tested were significantly different $(\mathrm{P}<0.05)$. VFA concentration of $\mathrm{R} 2, \mathrm{R} 1$, and $\mathrm{R} 3$ were the highest among the rations tested. The high VFA concentrations in the $\mathrm{R} 2, \mathrm{R} 1$, and $\mathrm{R} 3$ rations showed that the organic matter in its rations were easily degraded by rumen microbes. Agle et al. (2010) stated that the total VFA concentration may fall as low as $89.4 \mathrm{mM}$, or be in excess of $124 \mathrm{mM}$ (Lascano \& Heinrich, 2009) to support microbial growth. VFA concentrations in this test rations were $91.6 \%-126.1 \%$, implying that the rations were fermentable enough to provide VFA for rumen microbes.

Protein degradation into ammonia $\left(\mathrm{NH}_{3}\right)$ in the rumen fermentation in five rations tested were significantly different $(\mathrm{P}<0.05)$. Ammonia is the main source of $\mathrm{N}$ for microbial protein synthesis (Bach et al., 2005). Optimal ammonia concentration of rumen for rumen microbial activity is more than $4.86 \mathrm{mM}$ (McMurphy et al., 2011). Ammonia concentration found by Lascano \& Heinrichs (2009) were lower than $2 \mathrm{mg} / \mathrm{dl}(5 \mathrm{mg} / \mathrm{dL}=$ $3.6 \mathrm{mM})$, which was the minimal $\mathrm{NH}_{3}-\mathrm{N}$ concentration for microbial growth in rumen. Levels of ammonia produced in this study were 3.9-4.6 mM. The low ammonia concentration in this study could be related to the low degradability of protein source contained in each ration by microbes to produce ammonia. Protein sources in the rumen, partially can be degraded and cannot be degraded (Lascano \& Heinrichs, 2009). The protein can be degraded into amino acids and ammonia, so that the concentration of ammonia is strongly influenced by the protein content in the diet (Lascano \& Heinrichs, 2009). The ammonia concentrations in this study were directly proportional to the crude protein content in each test feed; it's supported by Despal et al. (2011). Chanthakhoun et al. (2014) reported that ruminal ammonia concentration increased linearly with increasing levels of crude protein in the diet. Crude protein of R2 was lower than other ration but ammonia concentration was not significantly different with R5. These can be caused by protein of R5 was degraded to ammonia that lower than to by pass protein.

Based on the analysis of variance, the five rations tested had significantly different dry matter digestibilities in the rumen $(\mathrm{P}<0.05)$. These differences can be caused by differences in the type of feed material used and the amount or percentage of its used. The high dry matter content of R2 was suspected because of the high activity of rumen microbes. This assumption was supported by the high concentration of VFA and $\mathrm{NH}_{3}$ produced in R2. Dry matter digestibility which was directly proportional to the VFA concentration indicated the source of energy was proportional to the growth and activity of rumen microbe. Dry matter and organic mat-

Table 3. Dry matter and organic matter digestibilities, $\mathrm{NH}_{3}$ and VFA concentrations of rations in the rumen of dairy cows

\begin{tabular}{ccccc}
\hline Treatment & VFA $(\mathrm{mM})$ & $\mathrm{NH}_{3}(\mathrm{mM})$ & $\mathrm{DMD}(\%)$ & OMD $(\%)$ \\
\hline R1 & $118.69 \pm 15.57^{\mathrm{a}}$ & $4.48 \pm 0.18^{\mathrm{a}}$ & $67.72 \pm 2.98^{\mathrm{bc}}$ & $69.43 \pm 2.40$ \\
R2 & $126.08 \pm 20.32^{\mathrm{a}}$ & $4.66 \pm 0.35^{\mathrm{a}}$ & $70.71 \pm 3.63^{\mathrm{a}}$ & $75.47 \pm 4.18$ \\
R3 & $124.07 \pm 18.77^{\mathrm{a}}$ & $4.43 \pm 0.14^{\mathrm{ab}}$ & $69.22 \pm 1.59^{\mathrm{ab}}$ & $71.68 \pm 1.81$ \\
R4 & $104.30 \pm 13.82^{\mathrm{ab}}$ & $3.91 \pm 0.40^{\mathrm{b}}$ & $66.46 \pm 2.70^{\mathrm{cd}}$ & $71.41 \pm 2.13$ \\
R5 & $91.64 \pm 13.64^{\mathrm{b}}$ & $3.91 \pm 0.34^{\mathrm{b}}$ & $64.80 \pm 4.00^{\mathrm{d}}$ & $69.13 \pm 2.46$ \\
\hline
\end{tabular}

Note: Means in the same column with different superscripts differ significantly $(\mathrm{P}<0.05)$. R1= Demo Farm ration; R1= NRC based ration; R3, R4, and R5= local dairy cattle farmer rations. 
Table 4. Feed intake, manure score, and milk production on dairy cows

\begin{tabular}{lccc}
\hline Variables & $\mathrm{R} 1$ & $\mathrm{R} 2$ & $\mathrm{R} 3$ \\
\hline $\begin{array}{l}\text { DMI of forages } \\
\text { (kg/h/d) }\end{array}$ & $7.94 \pm 1.08^{\mathrm{a}}$ & $4.86 \pm 0.45^{\mathrm{b}}$ & $6.64 \pm 0.46^{\mathrm{a}}$ \\
$\begin{array}{l}\text { DMI of concentrate } \\
\text { (kg h/d) }\end{array}$ & $7.30 \pm 1.01^{\mathrm{b}}$ & $11.02 \pm 0.98^{\mathrm{a}}$ & $9.21 \pm 0.63^{\mathrm{a}}$ \\
$\begin{array}{l}\text { DMI of forage : con- } \\
\text { centrate ratio }\end{array}$ & $52: 48$ & $31: 69$ & $42: 58$ \\
DMI of ration (kg h/d) & $15.25 \pm 2.09$ & $15.88 \pm 1.43$ & $15.85 \pm 1.09$ \\
DMI / BW (\%) & $2.99 \pm 0.00$ & $3.19 \pm 0.01$ & $3.04 \pm 0.25$ \\
Manure ccore & & & \\
$\quad$ Before & $2.41 \pm 0.38$ & $3.12 \pm 0.52$ & $2.88 \pm 0.55$ \\
$\quad$ After & $2.58 \pm 0.35$ & $2.57 \pm 0.36$ & $2.59 \pm 0.46$ \\
Milk production (L/d) & & & \\
$\quad$ Before & $17.03 \pm 1.97$ & $16.73 \pm 1.74$ & $17.11 \pm 1.44$ \\
$\quad$ After & $17.45 \pm 0.13$ & $16.99 \pm 1.24$ & $18.01 \pm 1.22$ \\
\hline
\end{tabular}

Note: Means in the same row with different superscripts differ significantly $(\mathrm{P}<0.05)$. $\mathrm{R} 1=$ Demo Farm ration; $\mathrm{R} 1=\mathrm{NRC}$ based ration; $\mathrm{R} 3=$ local dairy cattle farmer rations.

ter digestibility percentages in each ration have positive linear correlation. Based on the analysis of variance, organic matter digestibility of the five rations tested were not significantly different.

\section{Dry Matter Intake, Manure Score and Milk Production}

Consumption level is influenced by body weight and the type of feed (Adhani et al., 2012). Dry matter intake, manure score, and milk production of cows were presented in Table 4. Based on the analysis of variance, the amount of intake of dry matter forages in rations (R1, R2, and R3) were significantly different $(\mathrm{P}<0.05)$. Intake of dry matter forages of R1 and R3 were higher than that of $\mathrm{R} 2$. This difference can be caused by the higher forage contents of R1 and R3 rations than R2. Based on the analysis of variance, dry matter intake of concentrates were significantly different $(\mathrm{P}<0.05)$. Dry matter intake of concentrates in R1 was lower than in $\mathrm{R} 2$ and R3. This difference can be caused by the lower total content of concentrate in R1. Different contents of forages and concentrate in each ration affected drymatter intake of forages and concentrates ratio. Dry matter intake of forages and concentrates ratio in each ration were 52:48 (R1), 31:69 (R2) and 42:58 (R3). Musnandar (2011) stated that the best ratio between forages and concentrates which could give positive nutrient balance in dairy cattle was 50:50. Sterk et al. (2011) stated that $35: 65$ was the best ratio of forages and concentrates which improved milk quality in milk fatty acid content than 50:50 and 65:35. Aguerre et al. (2011) stated that increasing the $\mathrm{F}: \mathrm{C}$ ratio from $47: 53$ to $54: 45,61: 39$ and 68:32 had no effect on DMI, but could increase milk fat content and linearly decreased true protein, lactose, and SNF contents.

Based on the analysis of variance, dry matter (DM) intake of the three rations tested were not significantly different. The non-significant different in dry matter intake among treatments was probably due to the similar contents of the structural fibers.. Kendall et al. (2009) stated that the content of structural fiber in the diet is a major factor affecting intake and fulfillment of the rumen. Dairy cattle intake was limited by the content of the digestive tract when consumed feed containing a lot of structural fiber. Feed with high NDF or ADF content has a slow fermentation so that the residence time in the rumen was longer, which in turn will reduce the consumption of dry matter. Based on the analysis of variance, dry matter (DM) intake of R1, R2, and R3 were not significantly different. This can be caused by the dry matter intake of the three rations tested were not different. Dry matter requirement that were tailored to the body weight, milk fat, and weeks on milk of trial cows based on NRC (2001) were $2.23 \%$ in R1, 2.19\% in R2, and $2.11 \%$ in R3. Trial animals used in this study consumed test rations in the range of $2.99 \%-3.19 \%$ of body weight. Dry matter intake in this study were meet even exceed the requirements. Saijpaul et al. (2005) stated that the total dry matter intake was highly influenced by milk production and milk composition, which might be up to $15-20 \mathrm{~kg} / \mathrm{d}$.

Aspects of fecal evaluation were performed to see whether there were any digestive problems. Based on the analysis of variance, manure scores of cows that consumed R3 were not significantly different from R1 and R2. R3 had higher scores of manure numerically, because the content of crude protein is lower than other ration (R1 and R2). The similar result of Wells (2013) stated that the cow which consumed of diets with high crude protein $(>20 \%)$ and high TDN $(>68 \%)$ content will yield a more liquid or high moisture and low consistency, so manure score of that condition is low, while cow which consumed diets with lower protein content will result a higher evaluation scores.

Based on the analysis of covariance, the effects of three rations tested on milk production were not significantly different. Kusnadi \& Juarini stated that the average milk production by $\mathrm{FH}$ cows in Indonesia (2007) was $15 \mathrm{~L} / \mathrm{head} / \mathrm{d}$. Milk production of this study was 16.73-18.01 L/head/d. Test rations R1, R2, and R3 had increased milk production by an average of 0.42 , 0.26, and $0.90 \mathrm{~L} / \mathrm{head} / \mathrm{d}$, respectively. Increased milk production in cattle fed $\mathrm{R} 2$ and $\mathrm{R} 3$ rations due to the improved quality of feeds both by nutritive and quantitative aspects. $\mathrm{R} 1$ is ration has been used in Demo Farm before observation started so the experimental cows had well adapted to the ration. Numerically, R3 was the best ration to improve milk production. These can be caused by the higher content of waste of soy sauce using in this ration. Laryska \& Nurhajati (2013) reports that waste of soy sauce can improve milk production better than commercial concentrate. R3 is a based practice of the best local dairy farmer ration on the observation about a collection of nutritional status information before and R3 is the best feed that have been tested in vitro on previous research stage.

\section{Body Condition Score and Body Weight Gain}

Body condition score (BCS) and body weight gain were shown in Table 5. Roche et al. (2007) stated that 
Table 5. Body condition score and body weight gain on dairy cows

\begin{tabular}{lccc}
\hline Variables & $\mathrm{R} 1$ & $\mathrm{R} 2$ & $\mathrm{R} 3$ \\
\hline $\begin{array}{l}\text { Body condition } \\
\text { score }\end{array}$ & & & \\
$\quad$ Before & $3.20 \pm 0.29$ & $2.70 \pm 0.29$ & $3.20 \pm 0.29$ \\
$\quad$ After & $3.30 \pm 0.58$ & $2.80 \pm 0.29$ & $2.80 \pm 0.29$ \\
$\begin{array}{l}\text { Body weight gain } \\
\text { (kg/h/d) }\end{array}$ & $0.64 \pm 1.15$ & $0.72 \pm 0.43$ & $-0.07 \pm 0.70$ \\
$\quad$ & & & \\
$\quad$ Before & $509.67 \pm 70.44$ & $497.33 \pm 44.28$ & $522.67 \pm 17.62$ \\
$\quad$ After & $532.00 \pm 30.51$ & $522.67 \pm 32.33$ & $520.33 \pm 22.50$ \\
\hline
\end{tabular}

Note: $\mathrm{R} 1=$ Demo Farm ration; R1= NRC based ration; $\mathrm{R} 3=$ local dairy cattle farmer rations.

optimal BCS of cow to milk production was around 3.5 (1 to 5 scales). Based on the analysis of variance, the three rations tested did not significantly affect the final BCS of cows, as well as changes of BCS. Increased of BCS was found in cows fed R1 and R2, while cows fed with $\mathrm{R} 3$ ration showed a decrease in body condition score. The highest final BCS were indicated by cows fed $\mathrm{R} 1$ ration and this result was due to a better BCS during pretreatment period. It was suspected that a small percentages of body fat reserves were used as a source of energy for milk production as was indicated by the higher amount of R1 feed intake but lower milk production than cattle which were fed of R3 rations. Dairy cows fed R3 ration showed a decrease in the BCS and this result was caused by the used of most of the energy obtained from the ration consumed and fat reserves to increase milk production or milk composition. Roche et al. (2007b) stated that fatter cows had greater predisposition to lose body condition in early lactation which might be used for milk fat synthesis.

Body condition closely related to the cow body weight. Based on the analysis of variance, the three rations used did not significantly affect body weight gain of cattle. Body weight gain of cows fed $\mathrm{R} 3$ ration was negative, because of the body weight decrease. Decreased body weight in cattle fed R3 ration were followed by a decrease in the value of the BCS that implied that most of the body's fat reserves were used for milk production needs. As presented by Roche et al. (2007a) that the dairy cow will experience a loss of BCS for an increase in milk production in early lactation. Cows that lost more condition in early lactation produced more milk of greater fat and protein concentration, although a negative effect (large amounts loss of body condition) was observed in cows (Berry et al., 2007b). Cows fed R2 ration had higher body weight gain than other trial cows, indicating that nutrients consumed were successfully digested and absorbed in the body better than the other test rations. A loss of BCS was linearly associated with a higher lactation profile, higher peak milk yield, and lower persistency (Berry et al., 2007b).

\section{Technical and Economical Efficiencies}

Technical and economical efficiencies were presented in Table 6. The results of analysis of variance showed
Table 6. Technical and economical efficiencies

\begin{tabular}{cccc}
\hline \multirow{2}{*}{ Treatment } & \multicolumn{2}{c}{ Efficiency } & \multirow{2}{*}{$\begin{array}{c}\text { Price of rations } \\
\text { (IDR/L) }\end{array}$} \\
\cline { 2 - 3 } & Technical & Economical & \\
\hline R1 & $1.16 \pm 0.14$ & $1.74 \pm 0.21$ & $2510.3 \pm 330.4$ \\
R2 & $1.07 \pm 0.10$ & $1.78 \pm 0.18$ & $2502.9 \pm 237.2$ \\
R3 & $1.15 \pm 0.17$ & $2.27 \pm 0.30$ & $1965.3 \pm 221.8$ \\
\hline
\end{tabular}

Note: $\mathrm{R} 1=$ Demo Farm ration; R1= NRC based ration; R3= local dairy cattle farmer rations.

that technical efficiency of three rations tested were not significantly different. This was due to the intake of DM rations and milk production was not significantly different. Technical efficiency is the number of feed dry matter consumed to produce one liter of milk. Casper (2008) reported that feed efficiency summarized from 422 treatment means published in the scientific literature were $0.86-2.30$, with average was 1.51 .

Lower feed efficiency in test rations were allegedly caused by the energy of the ration DM intake was less efficiently used for the synthesis of milk as was also reported by Linn (2006) that the value of low efficiency can be caused by digestive problems or process of milk synthesis. Casper \& Mertens (2007) also reported that digestive problems (acidosis) increased heat produced per unit of digestible energy, which resulted in a poorer conversion of digestible energy into net energy available for productive purposes that eventually caused low feed efficiency. This study also showed that dry matter intake had negative correlation with the feed efficiency of the lactating dairy cow. Casper \& Mertens (2007) stated that the feed efficiency increase, the intake of DM was lower for dairy cows.

Variance analysis results showed that the economical feed efficiency of three test feeds were not significantly different. Economic efficiency of R1, R2, and R3 were 1.74, 1.78, and 2.27, respectively. Economic efficiency produced by $\mathrm{R} 1$ and $\mathrm{R} 2$ were in the range of normal efficiency $(>1.4)$ as was stated by Linn (2006), while R3 had a higher value. The higher value of economic efficiency is due to the cost of R3 ration was lower and the level of milk production by cows that consumed R3 was higher. R3 had the highest price i.e., IDR 1957.7, meaning that to produce one liter of milk needed feed costs of IDR 1957,7. Likewise with R2 and R3 each have a ration prices rate of IDR 2508.5, and IDR. 2502.7. The price of R3 showed a lower tendency. This means that a more efficient use of feed due to the lower cost will result in a higher increase in milk production that eventually can increase profits dairy farmer.

\section{CONCLUSION}

Demo Farm ration (R1), NRC based ration (R2) and farmer ration (R3) were three best rations in nutrient composition and fermentability. The three rations had similar milk production, performance, and efficiency. 


\section{REFERENCES}

Adhani, N., T. Nurhajati, \& A. T. S. Estoepangestie. 2012. Potensi pemberian formula pakan konsentrat komersial terhadap konsumsi dan kadar bahan kering tanpa lemak susu. Agroveteriner. 1:11-16.

Agle, M., A. N. Hristov, S. Zaman, C. Schneider, P. M. Ndegwa, \& V. K. Vaddellat. 2010. Effect of dietary concentrate on rumen fermentation, digestibility, and nitrogen losses in dairy cows. J. Dairy Sci. 93:4211-4222. http://dx.doi. org $/ 10.3168 / j d s .2009-2977$

Aguerre, M. J., M. A. Wattiaux, J. M. Powell, G. A. Broderick, \& C. Arndt. 2011. Effect on forage-to-concentrates ratio in dairy cow diets on emission of methane, carbon dioxide, and ammonia, lactation performance, and manure excretion. J. Dairy Sci. 94:3081-3093. http://dx.doi.org/10.3168/ jds.2010-4011

AOAC. 2005. Official Methods of Analysis of the Association of Analytical Chemist $18^{\text {th }}$ ed. Assoc. Off. Anal. Chem., Arlington.

Bach, A., S. Calsamiglia, \& M. D. Stern. 2005. Nitrogen metabolism in the rumen. J. Dairy Science. 88:9-21. http://dx.doi. org/10.3168/jds.S0022-0302(05)73133-7

Berry, D.P., K. A. Macdonald, K. Stafford, L. Matthews, \& J. R. Roche. 2007a. Associations between body condition score, body weight and somatic cell count and clinical mastitis in seasonally calving dairy cattle. J. Dairy Sci. 90:637-648. http://dx.doi.org/10.3168/jds.S0022-0302(07)71546-1

Berry, D. P., F. Buckley, \& P. Dillon. 2007b. Body condition score and live-weight effects on milk production in Irish Holstein-Friesian dairy cows. J. Animal. 1:1351-1359. http://dx.doi.org/10.1017/s1751731107000419

Busquet, M., S. S. Calsamiglia, A. Ferret, \& C. Kamel. 2006. Plant extracts affect in vitro rumen microbial fermentation. J. Dairy Sci. 89:761-771. http://dx.doi.org/10.3168/jds. S0022-0302(06)72137-3

Casper, D. P. \& D. R. Mertens. 2007. Feed efficiency of lactating dairy cows is related to dietary energy density. J. Dairy Sci. 90:407.

Casper, D. P. 2008. Factors Affecting Feed Efficiency of Dairy Cows. Tri-State Dairy Nutrition. Agri-King Inc, Fulton.

Chanthakhoun, V., M. Wanapat, J. Berg, \& S. Kang. 2014. Influence of crude protein and energy level on feed intake, ruminal ammonia nitrogen, and methylglyoxal production in swamp buffaloes (Bubalus bubalis). J. Anim. Plant Sci. 24:1716-1723.

Despal. 2007. Improving cocoa pod quality by urea, $\mathrm{NaOH}$ and cocoa pod ash alkali treatments for ruminant feedstuffs. Journal of Agricultural and Rural Development in Tropics and Subtropics. 63-69.

Despal, I. G. Permana, S. N. Safarina, \& A. J. Tatra. 2011. Penggunaan berbagai sumber karbohidrat terlarut air untuk meningkatkan kualitas silase daun rami. Med. Pet. 34:6976. http://dx.doi.org/10.5398/medpet.2011.34.1.69

Direktorat Jenderal Peternakan dan Kesehatan Hewan. 2013. Produksi susu nasional. www.radarpena.com/read/2014/06/05/10914/18/1/produksi-tak-maksimal-impor-susu-capai-80. (12 Februari 2015).

FAO (Food and Agriculture Organization of The United Nations) \& IDF (International Dairy Federation). 2011. Guide to Good Dairy Farming Practice. FAO Animal Production and Health \& Food and Agriculture Organization of The United Nations and International Dairy Federation. Rome.

Harvartinet, K. J. \& M. S. Allen. 2002. The effect of production level on feed intake, milk yield, and endocrine responses to two fatty acid supplements in lactating cows. J. Dairy Sci. 88:4018-4027. http://dx.doi.org/10.3168/jds.S00220302(05)73088-5
Hertanto, B. S. 2014. The comparative study of economic parameters (milk and feed price) on the efficiency of feed technology in dairy farm. Sains Peternakan. 12:49-55.

Jayanegara, A, A. S. Tjakradidjaja, \& T. Sutardi. 2006. Fermentabilitas dan kecernaan in vitro ransum limbah agroindustri yang disuplementasi kromium organik dan anorganik. Med. Pet. 29:54-62.

Kaldmae, H., O. Kart, A. Olt, A. Selge, \& I. Keres. 2009. Inoculant effects on red clover silage: fermentation products and nutritive value. Agronomy Research. 7:793-800.

Kendall, C., C. Leonard, O. C. Hoffman, \& D. K. Association. 2009. Intake and milk production of cows fed diets that differed in dietary neutral detergent fiber and neutral detergent fiber digestibility. J. Dairy Sci. 92:313-323. http:// dx.doi.org/10.3168/jds.2008-1482

Kusnadi, U. \& E. Juarini. 2007. Optimalisasi pendapatan usaha pemeliharaan sapi perah dalam upaya peningkatan produksi susu nasional. Wartazoa. 17:2.

Kusriningrum, R. S. 2011. Buku Ajar Perancangan Percobaan. Dani Abadi, Surabaya.

Laryska, N. \& T. Nurhajati. 2013. Peningkatan kadar lemak susu sapi perah dengan pemberian pakan konsentrat komersial dibandingkan dengan ampas tahu. Agroveteriner. 1:79-87.

Lascano, G. J. \& A. J. Heinrichs. 2009. Rumen fermentation pattern of dairy heifers fed restricted amounts of low, medium, and high concentrate diets without and with yeast culture. Livest. Sci. 124:48-57. http://dx.doi.org/10.1016/j. livsci.2008.12.007

Linn, J. 2006. Feed efficiency: its economics impact in lactating dairy cows. WCDS Advances in Dairy Technology 18:1928.

McGuffey R. K., R. Schoen, \& P. Studney. 2014. Progress on $8^{\text {th }}$ Edition of the Nutrient Requirements of Dairy Cattle. TriState Dairy Nutrition Conference. Pp. 85-90.

McMurphy, C. P., G. C. Duff, S. R. Sanders, S. P. Cuneo, \& N. K. Chirase. 2011. Effects of suplementing humates on rumen fermentation in Holstein steers. S. Afr. J. Anim. Sci. 41:134-140. http://dx.doi.org/10.4314/sajas.v41i2.71017

Musnandar, E. 2011. Efisiensi energi pada sapi perah holstein yang diberi berbagai imbangan rumput dan konsentrat. J. Penelitian Universitas Jambi Seri Sains. 13:53-58.

National Research Council. 2001. Nutrient Requirement of Dairy Cattle $7^{\text {th }} \mathrm{Ed}$. National Academy of Science. Washington DC (US).

Nugroho, H. D., I. G. Permana, \& Despal. 2015. Utilization of bioslurry on maize hydrophonic fodder as a corn silage supplement on nutrient digestibility and milk production of dairy cows. Med. Pet. 38:70-76. http://dx.doi. org/10.5398/medpet.2015.38.1.70

Nuhuyunan, L. E. 2010. Effects of addition of fermented mother liquor (FML) and mollases bindersin elephant grass wafer towards feed consumption, nutrient digestibility and average daily gain in bull. Jurnal Ilmu Peternakan. 5:111-117.

Pen, B., T. Iwama, M. Ooi, T. Saitoh, K. Kida, T. Iketaki, J. Takahashi, \& H. Hidari. 2006. Effect of potato by-products based silage on rumen fermentation, methane production and nitrogen utilization in Holstein steers. Asian-Aust. J. Anim. Sci. 19:1283-1290.

Roche, J. R., J. M. Lee, K. A. Macdonald, \& D. P. Berry. 2007a. Relationships between body condition score, body weight and milk production variables in pasture-based dairy cows. J. Dairy Sci. 92:5769-5801. http://dx.doi.org/10.3168/ jds.2009-2431

Roche, J. R., K. M. Macdonald, C. R. Burke, \& D. P. Berry. 2007b. Associations between body condition score, body weight and reproductive performance in seasonal-calving pasture-based dairy cattle. J. Dairy Sci. 90:376-391. http:// dx.doi.org/10.3168/jds.S0022-0302(07)72639-5 
Saijpaul S, R. S. Grewal, R. Kaur, \& P. K. Naik. 2005. Evaluation of some potential complete rations for economic milk production in crossbred cows. J. Anim. Nutr. Feed Tech. 5: 203-210.

Sretenovic, Lj., M. P. Petrovic, S. Aleksic, V. Pantelic, V. Katic, V. Bogdanovic, \& R. Beskorovajni. 2008. Influence of yeast, probiotics and enzymes in rations on dairy cows performances during transition. Biotechnology in Animal Husbandry. 24:33-43. http://dx.doi.org/10.2298/ BAH0806033S
Sterk, A. B. E. Johansson, H. Z. Taweel, M. Murphy, A. M. Van Vuuren, W. H. Hendriks, \& J. Dijkstra. 2011. Effects of forage type, forage to concentrate ratio and crushed linseed supplementation on milk fatty acid profile in lactating dairy cows. J. Dairy Sci. 94:6078-91. http://dx.doi. org/10.3168/jds.2011-4617

Wells, R. 2013. Manure Scoring Determines Supplementation Needs. The Samuel Robert Nobels Foundation, News and Views. US.

Yusdjah, Y. 2005. Kebijakan ekonomi industri agribisnis sapi perah di Indonesia. Analisis Kebijakan Pertanian 3:257268. 